\title{
A methodological approach to characterise Landslide Periods based on historical series of rainfall and landslide damage
}

\author{
O. Petrucci and A. A. Pasqua \\ CNR-IRPI, Via Cavour 4/6, 87036 Rende, Cosenza, Italy
}

Received: 29 June 2009 - Revised: 21 August 2009 - Accepted: 11 September 2009 - Published: 9 October 2009

\begin{abstract}
Landslide Periods (LPs) are defined as periods, shorter than a hydrological year, during which one or more landslide damage events occur in one or more sectors of a study area. In this work, we present a methodological approach, based on the comparative analysis of historical series of landslide damage and daily rainfall data, aiming to characterise the main types of LPs affecting selected areas. $\mathrm{Cu}$ mulative rainfall preceding landslide activation is assessed for short (1,2, 3, and 5 days), medium (7, 10, and 30 days) and long (60, 90, and 180 days) durations, and their Return Periods (RPs) are assessed and ranked into three classes (Class 1: $\mathrm{RP}=5-10$ years; Class 2: $\mathrm{RP}=11-15$; Class 3: $\mathrm{RP}>15$ years). To assess landslide damage, the Simplified Damage Index (SDI) is introduced. This represents classified landslide losses and is obtained by multiplying the value of the damaged element and the percentage of damage affecting it. The comparison of the RP of rainfall and the SDI allows us to indentify the different types of LPs that affected the study area in the past and that could affect it again in the future.

The results of this activity can be used for practical purposes to define scenarios and strategies for risk management, to suggest priorities in policy towards disaster mitigation and preparedness and to predispose defensive measures and civil protection plans ranked according to the types of LPs that must be managed.

We present an application, performed for a 39-year series of rainfall/landslide damage data and concerning a study area located in NE Calabria (Italy); in this case study, we identify four main types of LPs, which are ranked according to damage severity.
\end{abstract}

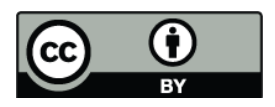

Correspondence to: O. Petrucci

(o.petrucci@irpi.cnr.it)

\section{Introduction}

The study of landslides triggered by rainfall can be carried out using two main kinds of approaches: 1) spatial analysis and 2) temporal analysis (Polemio and Petrucci, 2009). The former can be applied to areas that are widely prone to landsliding, and the latter can be applied to single sites or small areas. In the first case, the area should be homogeneous, while in the second, the studied phenomena should be stationary or assumed to be stationary (Crozier, 1986).

The scientific literature widely recognises rainfall as the most common triggering cause of landslides (Crozier, 1986; Corominas, 2001), but the relationship between rain and slope instability is not direct, due to the nonlinear role of the soil-water system (Schmidt and Dikau, 2004; Floris and Bozzano, 2008).

In temporal analysis, such as in this work, several approaches have been proposed to assess the threshold, namely, the minimum rainfall height (or intensity) required for landslide initiation (Campbell, 1975; Caine, 1980; Govi et al., 1985; Cancelli and Nova, 1985; Cascini and Versace, 1986; Cannon and Ellen, 1985; Keefer et al., 1987; Jibson, 1989; Finlay et al., 1997; Au, 1998; Polemio and Petrucci, 2000; Dai and Lee, 2001; Chien-Yuan et al., 2005; Guzzetti et al., 2007). The rain that triggers landslides varies from one area to the next and can change as a function of the mean annual precipitation; the magnitude of the event depends on the rainfall intensity and the season of occurrence. Besides the activation of single landslides, historical landslide series show that, in some areas, sequences of landslides can occur during almost the entire rainy season, causing damage trends that strongly increase throughout the rainy season. During these periods, along with landslides, floods and sea storms can also cause severe damage (Petrucci and Polemio, 2009; Petrucci et al., 2008).

Focusing on landslides occurrence, we can define Landslide Periods (LPs) as periods, shorter than a hydrological year, during which one or more landslide damage events

Published by Copernicus Publications on behalf of the European Geosciences Union. 
occur in one or more sectors of a study area. The increasing number of phenomena triggered during these periods, often along the road network, can block traffic and represent a problem for all of the agencies involved in managing emergency and civil protection actions. If these agencies can access real-time meteorological forecasting, and they know ahead of time the possible scenarios that can take place after a certain amount of expected rainfall, they can organise, in advance, specific management plans that take into account the type of landslide period.

In recent years, we have organised a database of historical landslides that occurred in Calabria during the past centuries (ASICal $\left.{ }^{1}, 2009\right)$. Then we set a support analysis framework to express landslide damage in numerical terms (Petrucci and Gullà, 2009). In the present work, we use these tools to develop a methodology based on the comparison of two historical series of data (landslide damage data and daily rainfall data), aiming to identify the types of LPs affecting a selected area. We stress that this is a large-scale approach that does not investigate landslide phenomena one by one: by analysing a series of landslides and triggering rainfall, it attempts to characterise the typical features of LPs affecting the analysed area, in order to manage their future occurrences.

An application of the proposed methodology to a sector of Calabria (Southern Italy) illustrates the results that can be obtained for a selected study area.

\section{Materials and methods}

The proposed method is based on a comparative analysis of two databases: a landslide damage database and one of daily rainfall. Landslides that occurred in a broad period (at least more than 10 years) and the rainfall characterising the same period are cross-checked in order to define the different types of scenarios in which, in the study area, landslide damage occurred in the past and could occur again in the future.

In selecting the dimension of a study area we must take into account that the aim of the study is to highlight the overall behaviour of the area, in terms of landslides triggered by rainfall. An absolute value of the size of the study area cannot be defined a priori because it depends on the rain gauge density, which defines the dimension of the Thiessen Polygons (hereafter referred to as Polygons) associated with the gauges. A reasonable study area must encompass almost three Polygons, and more than one municipality. These figures should allow for comparing both the rainfall series of different Polygons and the series of landslide damage, in order to highlight local effects, if any, which can complicate the understanding of the overall behaviour of the area.

In the following, the characteristics of the two databases are described, underlining the difficulties and assumptions that must be made in order to perform the analysis.

\footnotetext{
${ }^{1}$ Aree Storicamente Inondate in CALabria, http://www.camilab.unical.it/
}

\subsection{The rainfall database: data gathering and elaboration}

It is necessary that the rain gauges in the study area encompass a continuous historical series of daily rainfall data for a period exceeding 30 years. A GIS commercial software can be used to trace Thiessen Polygons, coupled with the rain gauges of the area. More sophisticated methods could be used to define the area around a gauge in which the amount of fallen rain can be assumed as represented by the amount of rain measured at the rain gauge. However, due to the fact that damage data are related to the municipal scale, we feel that the accuracy of the Thiessen Polygons approach is suitable for this study.

Cumulative rainfall events must be systematically analysed in order to account the effects of continuous rainy days, which increases the terrain humidity and predisposes it to landsliding. This aspect may not seem relevant for damaging phenomena that show an immediate response to intense rainfall (flash floods or shallow landslides), but for deep-seated landslides (mostly tied to prolonged rainfall), neglecting this aspect can cause an underestimation of rainfall responsible for the triggering.

Thus, daily rainfall is organised in a spreadsheet that assesses the Cumulative Rainfall (CRnj) for short (1, 2, 3 and 5 days), medium (7, 10 and 30 days) and long (60, 90 and 180 days) durations, for each gauge and each Hydrological Year (HY) (from 1 September to 31 August). In CRnj, n corresponds to $1,2,3,5,7,10,30,60,90$ and 180 consecutive days, and $\mathrm{j}$, ranging from 1 to 365 , is the number of days in the HY.

A Gumbel distribution can be used to compute the Return Period (RP), in years, of each CRnj. For each series of cumulative rainfall, the parameters of the distribution are evaluated by using the Moment Method. Using the abovementioned distribution, the RP for each CRnj can be assessed (Versace et al., 1989).

For each day in which landslide occurred, ten values of RPs, concerning rainfall that fell during the $1,2,3,5,7,10$, $30,60,90$ and 180 days before, are assessed. To simplify the comparison with damage data, for each block of rainfall duration (short, medium and long-lasting rainfall) we used the highest RP recorded within the block itself as a representative value. The abovementioned RPs are then classified as follows: Class 1: $\mathrm{RP}=5-10$ years; Class 2: $\mathrm{RP}=11-15$; Class 3: $\mathrm{RP}>15$ years.

\subsection{The landslide damage database: data gathering}

Historical research can be a useful tool to obtain the series of damaging landslides that have affected a study area. Many authors have shown the importance of lessons from the past in the management of natural hazards (Dore, 2003; Colten and Sumpter, 2008) and the various types of documents in which historical data can be found (Guzzetti et al., 1994; 
Ibsen and Brunsden, 1996; Cuesta et al., 1999; Guzzetti, 2000; Glade, 2001; Barnikel and Becht, 2003; Glaser and Stangl, 2004; Blong, 2004; Llasat et al., 2006; Kirschbaum et al., 2009).

Nevertheless, difficulties can arise because of either imprecise temporal and spatial descriptions of phenomena or ambiguities in the terminology characterising non-scientific data sources (Flageollet et al., 1999).

To collect landslide damage data, two steps must be taken:

1. identify available national/regional databases containing data on landslide damage, and

2. plan historical research in order to gather the entire dataset (if the databases mentioned in point 1 are not available), or in order to fill gaps (when available databases are characterised by a low spatial/temporal resolution).

Regardless of the type of source from which data are gathered, some restrictions must be taken into account (Petrucci and Pasqua, 2008; Petrucci and Gullà, 2009b).

Research can never be considered complete because of various causes:

- Accidents (i.e., fires), causing document losses.

- Unavailability of information sources located in inaccessible archives.

- Reporting bias due to the irregularity of data availability over time: information concerning older events is generally less plentiful than information pertaining to recent phenomena.

- Data gaps due to the areal irregularity of data availability: data concerning less populated areas are very rare. The landslides able to "leave a trace", in terms of historical documents, must have damaged something. Except for scientific articles, numerous sources are more related to the effects (damage) than the phenomenon itself. Then they describe only those landslides that caused some damage, allowing us to obtain the series of damaging landslides (instead of the series of landslides).

Moreover, two further points have to be taken into account:

- Damage is often considered in reference to municipalities, especially in administrative data sources.

- Uncertainty can affect the dates of the landslide events. Reimbursement requests filled out after several landslide activations over wide areas were often recorded using prescribed forms, in which there is the indication of the "winter" in which a selected landslide occurred (i.e.: ...landslides triggered by rainfall occurred during the winter season 1951-1952). In this case, the coeval phenomena that occurred in the same area and for which a precise date of occurrence is available must be analysed. The dates of occurrence of these phenomena set the limits of a "period of occurrence" that can be reasonably assigned to the phenomenon having no date.

Each gathered document must be typed and converted into a database record containing the following fields: a) the date of the landslide damage occurrence, b) the municipality in which it occurred and c) available details about the phenomenon and the related damage.

The name of the municipality where damage occurred is quoted in almost all of the data, but the place names of areas hit are often not pinpointed. Even if a place name is available, the area specifically affected cannot be delimited: usually, unless the document is a scientific article, the author does not supply maps of the hit areas.

To be strict, historical data allow us to identify the occurrence/non-occurrence of landslide damage only in the municipality boundaries, so for the sake of simplicity, the study area can be considered as divided into municipal cells.

\subsubsection{The Simplified Damage Index}

Several studies concerning the methodologies for text-based inventories of landslides are available (Petley et al., 2005; Kirschbaum et al., 2009); however, no standard methodologies to convert damage data into numerical indices can be found. This is due to the fact that we deal with noninstrumental data, that is, text descriptions from which phenomena (landslides) and effects (damage) must be inferred.

According to previous works, each landslide damage information can be converted into a damage index (Petrucci and Gullà, 2009a, b), accounting for direct, indirect and intangible damage caused.

This work introduces a Simplified Damage Index (SDI), which only considers direct landslide damage. Direct damage is defined as all of those physical impacts that lead to either destruction or deformation that reduces the functionality of an element and leads to damage to people, who may be either killed or injured (Swiss Re, 1998; Middelman, 2007). The use of a simplified index is justified in dealing with numerous and very old landslides, for which either indirect or intangible damage data are unavailable.

The SDI is assessed by means of a spreadsheet: a Component of Damage (CD) can be calculated by multiplying the value of each damaged element (Value of Element), ranging from 1 to 0.25 , by the level of loss, which is a measure of the percentage of loss affecting it because of the landslide (L4: complete loss; L3: high loss; L2: medium loss; L1: low loss) (Table 1). We have to stress that the value of each element is a relative parameter, fixed in an arbitrary scale, and it is a starting assumption set by us based on the analysis of the damage dataset and focusing on the assessment of repairing cost of each element. People have been assumed as the element characterised by the highest value. 
Table 1. Simplified Damage Index Assessment. On the left: sorted into sections, elements that can be damaged by landslides and their relative value (Value of Elements) (bold numbers), defined on an arbitrary scale. On the right: Levels of Loss (indicate numbers), which have been set as follows: L4: complete loss; L3: high loss; L2: medium loss; L1: low loss. Each Contribution to Damage (CD) is labelled with the number of the line to which it belongs. In the operative version, the numbers are hidden. When the operator types an $x$ letter in the cross cells of a selected element and a certain level of loss, hidden formulas use these numbers to assess CDs (by multiplying the value of the hit element by the level of loss that it suffered) and the Simplified Damage Index (by summing all of the CDs) (after Petrucci and Gullà, 2009b, modified).

\begin{tabular}{|c|c|c|c|c|c|c|c|c|c|c|}
\hline \multicolumn{11}{|c|}{ Simplified Damage Index Assessment } \\
\hline \multicolumn{2}{|c|}{ Sections } & \multicolumn{4}{|c|}{ Elements } & \multicolumn{4}{|c|}{ Levels of loss } & \multirow[t]{2}{*}{$\mathrm{CD}$} \\
\hline & & & & & & L4 & L3 & $\mathrm{L} 2$ & L1 & \\
\hline & \multirow{16}{*}{ 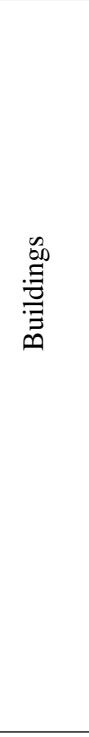 } & \multicolumn{4}{|l|}{ Public buildings } & & & & & \\
\hline & & \multirow{5}{*}{\multicolumn{3}{|c|}{$\begin{array}{l}\text { City hall } \\
\text { Barracks } \\
\text { Hospital } \\
\text { School } \\
\text { Church } \\
\end{array}$}} & 1 & 1 & 0.75 & 0.5 & 0.25 & $\mathrm{CD}_{1}$ \\
\hline & & & & & 1 & 1 & 0.75 & 0.5 & 0.25 & $\mathrm{CD}_{2}$ \\
\hline & & & & & 1 & 1 & 0.75 & 0.5 & 0.25 & $\mathrm{CD}_{3}$ \\
\hline & & & & & 0.75 & 1 & 0.75 & 0.5 & 0.25 & $\mathrm{CD}_{4}$ \\
\hline & & & & & 0.75 & 1 & 0.75 & 0.5 & 0.25 & $\mathrm{CD}_{5}$ \\
\hline & & Private houses & Inhabited & $\begin{array}{l}\text { Temporarily } \\
\text { inhabited }\end{array}$ & Uninhabited & & & & & \\
\hline & & 1 building & 0.75 & 0.5 & 0.25 & 1 & 0.75 & 0.5 & 0.25 & $\mathrm{CD}_{6}$ \\
\hline & & $2-10$ buildings & 1 & 0.75 & 0.5 & 1 & 0.75 & 0.5 & 0.25 & $\mathrm{CD}_{7}$ \\
\hline & & $>10$ buildings & 1 & 1 & 0.75 & 1 & 0.75 & 0.5 & 0.25 & $\mathrm{CD}_{8}$ \\
\hline & & & 1 building & & 0.25 & 1 & 0.75 & 0.5 & 0.25 & $\mathrm{CD}_{9}$ \\
\hline & & Loss of furnishings and assets & $2-10$ buildi & ngs & 0.5 & 1 & 0.75 & 0.5 & 0.25 & $\mathrm{CD}_{10}$ \\
\hline & & & $>10$ buildir & & 0.75 & 1 & 0.75 & 0.5 & 0.25 & $\mathrm{CD}_{11}$ \\
\hline & & & 1 building & & 0.25 & 1 & 0.75 & 0.5 & 0.25 & $\mathrm{CD}_{12}$ \\
\hline & & Loss of assets outside the buildings (i.e., cars) & $2-10$ buildi & ngs & 0.5 & 1 & 0.75 & 0.5 & 0.25 & $\mathrm{CD}_{13}$ \\
\hline & & & $>10$ buildir & & 0.75 & 1 & 0.75 & 0.5 & 0.25 & $\mathrm{CD}_{14}$ \\
\hline \multirow{13}{*}{$\mathrm{B}$} & \multirow{13}{*}{$\begin{array}{l}\tilde{\tilde{z}} \\
\tilde{0} \\
\hat{1}\end{array}$} & & & Bridge & 1 & 1 & 0.75 & 0.5 & 0.25 & $\mathrm{CD}_{15}$ \\
\hline & & Highway & & Tunnel & 1 & 1 & 0.75 & 0.5 & 0.25 & $\mathrm{CD}_{16}$ \\
\hline & & & & Roadway & 1 & 1 & 0.75 & 0.5 & 0.25 & $\mathrm{CD}_{17}$ \\
\hline & & & & Bridge & 1 & 1 & 0.75 & 0.5 & 0.25 & $\mathrm{CD}_{18}$ \\
\hline & & State road & & Tunnel & 0.75 & 1 & 0.75 & 0.5 & 0.25 & $\mathrm{CD}_{19}$ \\
\hline & & & & Roadway & 0.75 & 1 & 0.75 & 0.5 & 0.25 & $\mathrm{CD}_{20}$ \\
\hline & & & & Bridge & 1 & 1 & 0.75 & 0.5 & 0.25 & $\mathrm{CD}_{21}$ \\
\hline & & County road & & Tunnel & 0.75 & 1 & 0.75 & 0.5 & 0.25 & $\mathrm{CD}_{22}$ \\
\hline & & & & Roadway & 0.25 & 1 & 0.75 & 0.5 & 0.25 & $\mathrm{CD}_{23}$ \\
\hline & & & & Bridge & 0.75 & 1 & 0.75 & 0.5 & 0.25 & $\mathrm{CD}_{24}$ \\
\hline & & Municipal road & & Tunnel & 0.5 & 1 & 0.75 & 0.5 & 0.25 & $\mathrm{CD}_{25}$ \\
\hline & & & & Roadway & 0.25 & 1 & 0.75 & 0.5 & 0.25 & $\mathrm{CD}_{26}$ \\
\hline & & Country road & & Roadway & 0.25 & 1 & 0.75 & 0.5 & 0.25 & $\mathrm{CD}_{27}$ \\
\hline \multirow{6}{*}{$\mathrm{C}$} & \multirow{6}{*}{ 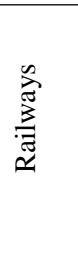 } & & & Bridge & 1 & 1 & 0.75 & 0.5 & 0.25 & $\mathrm{CD}_{28}$ \\
\hline & & State railway & & Tunnel & 1 & 1 & 0.75 & 0.5 & 0.25 & $\mathrm{CD}_{29}$ \\
\hline & & & & Roadway & 0.75 & 1 & 0.75 & 0.5 & 0.25 & $\mathrm{CD}_{30}$ \\
\hline & & & & Bridge & 1 & 1 & 0.75 & 0.5 & 0.25 & $\mathrm{CD}_{31}$ \\
\hline & & Regional railway & & Tunnel & 0.75 & 1 & 0.75 & 0.5 & 0.25 & $\mathrm{CD}_{32}$ \\
\hline & & & & Roadway & 0.5 & 1 & 0.75 & 0.5 & 0.25 & $\mathrm{CD}_{33}$ \\
\hline \multirow{5}{*}{$\mathrm{D}$} & \multirow{5}{*}{ 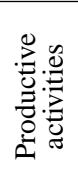 } & Industrial & & & 1 & 1 & 0.75 & 0.5 & 0.25 & $\mathrm{CD}_{34}$ \\
\hline & & Commercial & & & 0.75 & 1 & 0.75 & 0.5 & 0.25 & $\mathrm{CD}_{35}$ \\
\hline & & Handicraft & & & 0.5 & 1 & 0.75 & 0.5 & 0.25 & $\mathrm{CD}_{36}$ \\
\hline & & Tourism & & & 0.75 & 1 & 0.75 & 0.5 & 0.25 & $\mathrm{CD}_{37}$ \\
\hline & & Farming & & & 0.25 & 1 & 0.75 & 0.5 & 0.25 & $\mathrm{CD}_{38}$ \\
\hline
\end{tabular}


Table 1. Continued.

\begin{tabular}{|c|c|c|c|c|c|c|c|c|}
\hline \multicolumn{9}{|c|}{ Simplified Damage Index Assessment } \\
\hline \multicolumn{2}{|c|}{ Sections } & \multicolumn{2}{|l|}{ Elements } & \multicolumn{4}{|c|}{ Levels of loss } & \multirow[t]{2}{*}{$\mathrm{CD}$} \\
\hline & & & & $\mathrm{L} 4$ & L3 & L2 & L1 & \\
\hline \multirow{5}{*}{$\mathrm{E}$} & \multirow{5}{*}{ 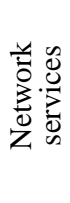 } & Gas pipeline & 1 & 1 & 0.75 & 0.5 & 0.25 & $\mathrm{CD}_{39}$ \\
\hline & & Electric line & $\mathbf{1}$ & 1 & 0.75 & 0.5 & 0.25 & $\mathrm{CD}_{40}$ \\
\hline & & Telephone line & 0.5 & 1 & 0.75 & 0.5 & 0.25 & $\mathrm{CD}_{41}$ \\
\hline & & Aqueduct & 0.75 & 1 & 0.75 & 0.5 & 0.25 & $\mathrm{CD}_{42}$ \\
\hline & & Drainage system & 0.5 & 1 & 0.75 & 0.5 & 0.25 & $\mathrm{CD}_{43}$ \\
\hline \multirow{5}{*}{$\mathrm{F}$} & \multirow{5}{*}{$\begin{array}{l}\frac{0}{2} \\
\frac{0}{0} \\
\text { م. }\end{array}$} & & & 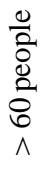 & $\begin{array}{l}\frac{0}{0} \\
\tilde{0} \\
0 \\
0 \\
0 \\
0 \\
0 \\
0\end{array}$ & 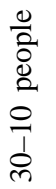 & 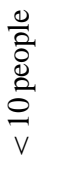 & \\
\hline & & Victims & 1 & 1 & 0.75 & 0.5 & 0.25 & $\mathrm{CD}_{44}$ \\
\hline & & Badly hurt & 1 & 1 & 0.75 & 0.5 & 0.25 & $\mathrm{CD}_{45}$ \\
\hline & & Light physical damage & 0.5 & 1 & 0.75 & 0.5 & 0.25 & $\mathrm{CD}_{46}$ \\
\hline & & Temporary shock conditions & 0.25 & 1 & 0.75 & 0.5 & 0.25 & $\mathrm{CD}_{47}$ \\
\hline
\end{tabular}

For each damage datum in a selected municipality, a sheet like that in Table 1 must be filled, in order to obtain an SDI expressing the damage that occurred in each analysed case. By selecting an element and a level of loss, the CD for the selected row is assessed; the SDI is the sum of all CDs, that is, the total damage caused in a landslide case. Each damage case can be tied to one or more landslides that occurred in a certain municipality because, as previously stated, historical documents do not present maps of areas hit by landslides. Therefore, damage represents a final result at the municipal scale which is to some extent independent of the characteristics of the phenomenon that caused it.

Since damage data refer to the municipal cells, and rainfall data refer to rain gauges (and Thiessen Polygons), in order to compare rainfall and damage, a rescaling procedure in a GIS environment must be performed. Basically, each Polygon is made up of several municipal sectors; each sector has an area representing a defined percentage of the area of the Polygon to which it belongs. The percentage of area that a selected municipality occupies in a Polygon multiplied by the SDI recorded in the same municipality represent the contribution of the selected municipality to the damage recorded in the Polygon. By summing the contributions of all the municipalities included in the Polygon, the SDI of the analysed Polygon is obtained (Petrucci and Pasqua, 2008). The SDIs, assessed for each Polygon in each case, are then ranked into three classes: Class 1: $\mathrm{SDI}<5$; Class 2: $\mathrm{SDI}=5-10$; Class 3: $\mathrm{SDI}>10$.

This simplified but systematic approach allows us to obtain a representative numerical value for the damage caused by each landslide that can be easily compared to rainfall.

\subsection{Comparative analysis of rainfall and damage}

Once the data contained in the two databases have been treated, their comparative analysis allows us to describe the way in which landslide damage can occur in the study area (Fig. 1).

By chronologically sorting landslide damage data, two main kinds of temporal distributions of data can be identified: Landslide Periods and Landslide Events.

A Landslide Period (LP) is a period, shorter than a hydrological year, during which one or more landslide damage events occur in one or more Polygons in the area.

A Landslide Event (LE) is a case in which landslide damage data are recorded during one day in one or more Polygons of the area.

LPs, which usually cause the most severe damage, develop over prolonged periods, so an approach intended for planning emergency management makes sense. The surveyed LPs are thus characterised in terms of: season of occurrence, duration, damage severity and rainfall exceptionality. According to these features, some types of LP scenarios that recurred several times in the series (and can be expected to repeat in the future) can be outlined. For each of these scenarios, different strategies can be planned to successfully manage them.

\section{A case study in Calabria (Southern Italy)}

The study area is located in Calabria (Southern Italy), a region made up of allochthonous crystalline rocks (Palaeozoic to Jurassic in age) stacked, during the middle Miocene (Tortorici, 1982), over carbonate units (Ogniben, 1973). Neogene flysch fills the tectonic depressions. Tectonic stresses 


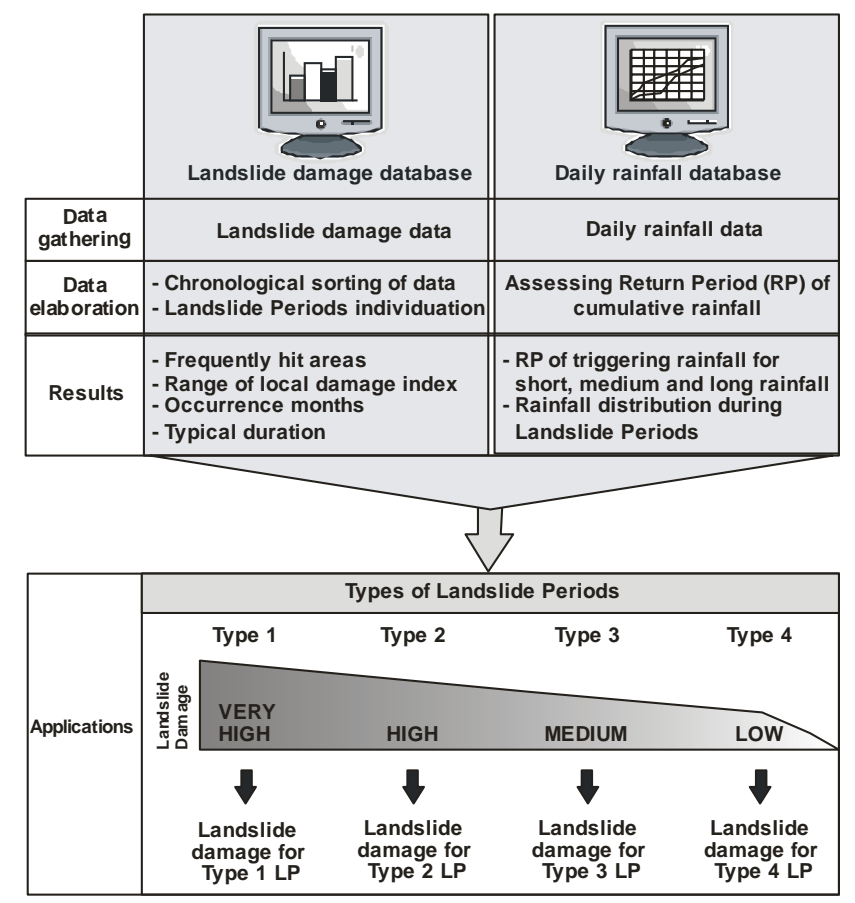

Fig. 1. Flow chart describing the proposed methodology to characterise LPs. Data gathered and uploaded into the two databases are used to obtain results useful in setting emergency plans specific for each type of landslide period.

and climatic conditions deteriorate the characteristics of the rocks, predisposing slopes to instability phenomena. The climate is Mediterranean, with dry summers and wet winters: the mean regional annual rainfall is $1151 \mathrm{~mm}$.

\subsection{Study area framework}

The study area is located in the NE sector of Calabria: it is composed of four polygons covering an area of $389.3 \mathrm{~km}^{2}$ and contains ten municipalities. Two of the four rain gauges of the area (N.2 and N.4) are located over $800 \mathrm{~m}$ a.s.l., one at $237 \mathrm{~m}$ a.s.l. (N.1), and the last is in the coastal plain, at $7 \mathrm{~m}$ a.s.l. (N.3). The main features of the gauges and the related Polygons are shown in Fig. 2 and Table 2.

Due to its position and characteristics, this area represents a homogeneous sector from a geological, geomorphological and climatic point of view.

The morphological setting of the area is dominated by the presence of a main river network made up of ephemeral streams having river beds often larger than one kilometre, completely dry for almost the entire summer season and affected by severe flash floods during the winter (Sabato and Tropeano, 2004). Along the flanks of either small ravines or the main river network, the slopes undergo further instability phenomena, locally increased by river erosion.
Flysch complexes, showing chaotic structure, crop out widely in hilly to coastal sectors (CASMEZ, 1970-1971) of the study area. Here instability phenomena are mainly tied to differences in permeability characterising the lithologies alternating in the flysch complexes.

Landsliding is the dominant process of slope shaping: both deep seated and shallow landslides affect the different sectors of the area, according to local slope geometry and outcropping lithologies.

Depending on the strata orientation, water infiltration can allow sliding of the rigid strata, mainly made up of sandy materials, on most plastic and impervious clayey strata. Thus, medium- or deep-seated landslides affecting entire slopes can cause damage to road and railway networks (both located along the coast), as has often occurred in the past (Lanzafame and Mercuri, 1975; Petrucci et al., 2009).

A detailed survey carried out in the Ferro river basin, representing about $60 \%$ of the study area, reports that landslides are to a great extent typologically complex: most of the rotational-translational slides evolve, in time and space, into earth or mud flow. Ancient landslides prevail over recent ones, but active phenomena are more numerous than dormant ones (Carrara et al., 1979).

From a climatic point of view, this is the driest part of Calabria: the mean annual rainfall, ranging from 576 to $817 \mathrm{~mm}$, is well below the mean values characterising the western sector of the region (ranging between 1200 and $1800 \mathrm{~mm}$ ).

The population density $\left(45 \mathrm{inh} / \mathrm{km}^{2}\right)$ is lower than the mean regional value $\left(133 \mathrm{inh} / \mathrm{km}^{2}\right)$ : the lowest values pertain to the innermost municipalities, and the highest pertain to the coastal areas, where the morphology makes it possible to place facilities and settlements, especially just along the coast.

\subsection{Gathering of rainfall and landslide damage data}

A study period of $39 \mathrm{HYs}$ (from 1 September 1959 to $31 \mathrm{Au}-$ gust 1997) was selected based on the absence of data gaps in the daily rainfall series of all the rain gauges in the area. Since 1997, the rain gauge N.1 (Table 2) has not been working, so, for the last 12 years, the comparison between rainfall and landslide damage cannot be performed. For the analysed period, historical data concerning damaging landslides triggered by rainfall were sought in various specialised databases (ASICal; SICI, 2009, available at: http://www.irpi.cnr.it/), in landslide damage data collections (Petrucci et al., 2009) and in the Historical Archive of the CNR-IRPI of Cosenza, an archive containing more than 10000 paper documents from various Calabrian agencies. To focus on landslides triggered by rainfall, data concerning phenomena triggered by any other phenomenon were rejected.

For the analysed period, 169 landslide damage data were found. None of the analysed cases produced any injuries or fatalities; the most frequently damaged element was the road network $(46 \%)$, followed by public and private buildings 

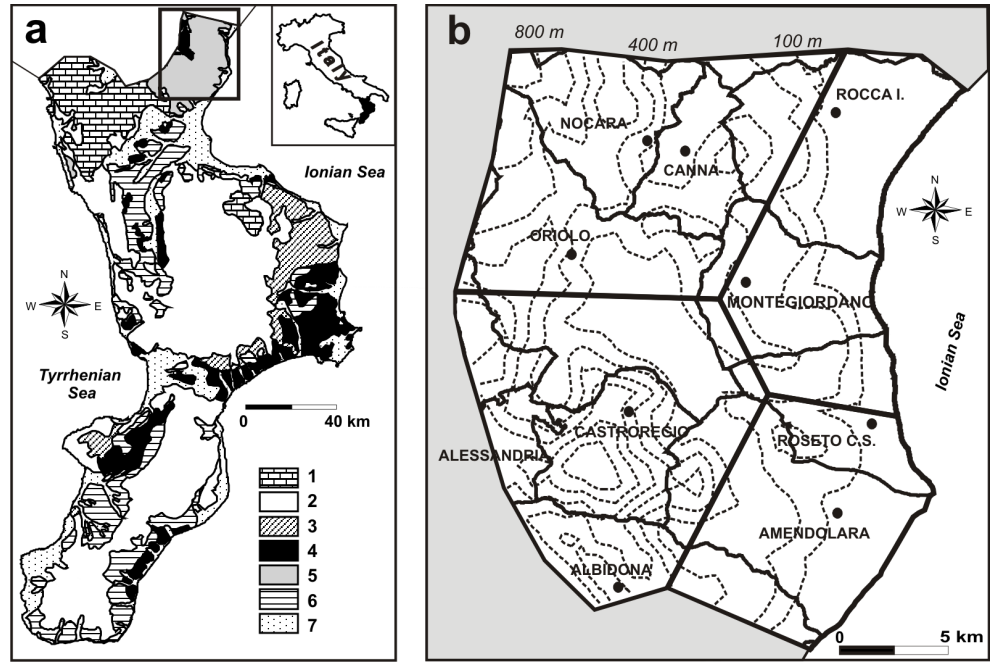

Fig. 2. (a) Simplified geological sketch of the Calabria region, study area (bordered by the black square) and location of the Calabria region on the Italian peninsula. In the legend: 1) limestone and dolostone; 2) metamorphic and igneous rocks; 3) clays, marls, and evaporitic rocks; 4) sandstones, marly clays, and limestone marls; 5) flysch and clayey formations; 6) conglomerates, sands, and sandstones and 7) alluvial deposits. (b) Study area. The straight black lines delimitate the Polygons in which the area is subdivided; irregular black lines represent municipal boundaries (the name of each municipality is also indicated); dashed lines are contour lines.

Table 2. Thiessen Polygons of the study area. On the left, under the label Polygons, the main characteristics of the Polygons are reported: the Polygon number $(\mathrm{N})$, the name of the Polygon, the area of the Polygon, the density population of the Polygon, the altitude of the rain gauge, the mean annual rainfall of the rain gauge, the percentage of the study area included in the Polygon, the number of landslide data collected for the study period and the value of SDI summed for all of the landslide cases surveyed. On the right, under the label Municipalities, the municipalities belonging to each Polygon are indicated, together with their population density and the area of each municipality included in each Polygon.

\begin{tabular}{|c|c|c|c|c|c|c|c|c|c|c|c|}
\hline \multirow[b]{2}{*}{ N. } & \multirow[b]{2}{*}{ Name } & \multicolumn{4}{|c|}{ Polygons } & \multirow[b]{2}{*}{$\begin{array}{l}\% \text { of } \\
\text { study } \\
\text { area }\end{array}$} & \multirow[b]{2}{*}{$\begin{array}{l}\text { N. of } \\
\text { landslide } \\
\text { data }\end{array}$} & \multirow[b]{2}{*}{$\begin{array}{l}\text { Total } \\
\text { SDI }\end{array}$} & \multicolumn{3}{|c|}{ Municipalities } \\
\hline & & $\begin{array}{l}\text { Area } \\
\left(\mathrm{km}^{2}\right)\end{array}$ & $\begin{array}{l}\begin{array}{l}\text { Density } \\
\text { population }\end{array} \\
\left(\mathrm{Inh} / \mathrm{km}^{2}\right)\end{array}$ & $\begin{array}{l}\text { Rain } \\
\text { gauge } \\
\text { altitude } \\
\text { (ma.s.l.) }\end{array}$ & $\begin{array}{l}\text { Mean } \\
\text { annual } \\
\text { rainfall } \\
(\mathrm{mm})\end{array}$ & & & & Name & $\begin{array}{l}\begin{array}{l}\text { Density } \\
\text { population }\end{array} \\
\left(\mathrm{Inh} / \mathrm{km}^{2}\right)\end{array}$ & $\begin{array}{l}\text { Area } \\
\text { included in } \\
\text { the polygon } \\
\left(\mathrm{km}^{2}\right)\end{array}$ \\
\hline 1 & Amendolara & 75.22 & 48 & 237 & 608 & 19 & 41 & 88.07 & $\begin{array}{l}\text { Amendolara } \\
\text { Albidona } \\
\text { Roseto Capo Spulico }\end{array}$ & $\begin{array}{l}3147 \\
1784 \\
1759\end{array}$ & $\begin{array}{l}47.49 \\
12.91 \\
14.82\end{array}$ \\
\hline 2 & Castroregio & 111 & 37 & 820 & 817 & 29 & 60 & 82.49 & $\begin{array}{l}\text { Alessandria del Carretto } \\
\text { Amendolara } \\
\text { Albidona } \\
\text { Castroregio } \\
\text { Montegiordano } \\
\text { Oriolo } \\
\text { Roseto Capo Spulico }\end{array}$ & $\begin{array}{l}745 \\
3147 \\
1784 \\
480 \\
2144 \\
2964 \\
1759\end{array}$ & $\begin{array}{l}4.56 \\
12.92 \\
15.49 \\
37.80 \\
3.12 \\
35.56 \\
1.54\end{array}$ \\
\hline 3 & $\begin{array}{l}\text { Montegiordano } \\
\text { Scalo }\end{array}$ & 79.87 & 61 & 7 & 576 & 21 & 26 & 63.67 & $\begin{array}{l}\text { Montegiordano } \\
\text { Rocca Imperiale } \\
\text { Roseto Capo Spulico }\end{array}$ & $\begin{array}{l}2144 \\
3352 \\
1759\end{array}$ & $\begin{array}{l}27.62 \\
38.19 \\
14.06\end{array}$ \\
\hline 4 & Nocara & 123.2 & 36 & 830 & 755 & 32 & 42 & 69.58 & $\begin{array}{l}\text { Canna } \\
\text { Castroregio } \\
\text { Montegiordano } \\
\text { Nocara } \\
\text { Oriolo } \\
\text { Rocca Imperiale }\end{array}$ & $\begin{array}{l}869 \\
480 \\
2144 \\
556 \\
2964 \\
3352\end{array}$ & $\begin{array}{l}20.17 \\
1.16 \\
4.86 \\
33.72 \\
47.43 \\
15.9\end{array}$ \\
\hline
\end{tabular}


(25\%), network services (11\%), retaining walls (9\%), productive activities (industrial, commercial, handicraft, farming and tourism) and railways (both affected in $4 \%$ of cases).

\subsection{Analysis of landslide damage data}

Because of the types of documents from which data were gathered (refund requests, technical reports assessing damage, etc.), the collected data concern landslides that caused some kind of damage.

Figure 3a depicts the annual series of landslide damage recorded during the study period, Polygon by Polygon. For 28 of the 39 analysed HYs, at least one landslide damage event is recorded in at least one Polygon of the area. The 11 HYs that are damage-free are mainly from the 1960's. The maximum number of data per HY (22 cases) is found at the beginning of the study period (HY 1959-1960), followed by a second maximum (21 cases) located in the 1970's (HY 1972-1973).

Figure $3 \mathrm{~b}$ represents the Simplified Damage Index of the Year $\left(\mathrm{SDI}_{Y}\right)$ recorded for each HY of the period, summarising the total damage caused, year by year and Polygon by Polygon. Based on the analysed period, a decreasing trend for both the number of damage data and the $\mathrm{SDI}_{Y}$ can be seen.

The study area can experience HYs characterised either by few landslides, inducing severe damage, or numerous landslides that do not cause a high total damage.

Finally, Fig. 3c indicates the Total Annual Rainfall (TAR) that fell during each HY, which was obtained by summing, year by year, the total amount of rain that fell on the four rain gauges of the area. This diagram also shows a decreasing trend throughout the study period, as well as the fact that the total amount of rainfall is correlated to neither the number of data nor the amount of damage (Fig. 3a and b). The maximum value of TAR $(4244.3 \mathrm{~mm})$ is recorded in the HY 1959-1960, which is a year characterised by high values of both the number of damage data and $\mathrm{SDI}_{Y}$. Nevertheless, the HY 1972-1973, characterised by the maximum $\mathrm{SDI}_{Y}$ value, shows quite a low TAR $(2699.2 \mathrm{~mm})$, while a high value of TAR $(3579.5 \mathrm{~mm})$ was recorded in the HY 1990 1991, which shows a high number of data but a quite low $\mathrm{SDI}_{Y}$ (4.69).

To locally investigate this aspect, we can assess for each Polygon the parameter $K_{P}$, defined by Eq. (1):

$K_{P}=\operatorname{TAR}_{P} / \mathrm{MAR}_{P}$

where $\operatorname{TAR}_{P}$ is the Total Annual Rainfall that fell on Polygon $\mathrm{P}$ during a selected HY, and $\mathrm{MAR}_{P}$ is the Mean Annual Rainfall for the same Polygon. $K_{P}$ allows us to appreciate the exceptionality of annual rainfall with respect to the mean value and to compare it to the values of $\mathrm{SDI}_{Y}$.

For instance, for Polygon N.1, the highest values of $\mathrm{SDI}_{Y}$ are recorded in HYs for which the $K_{P}$ is higher than 1.10 .
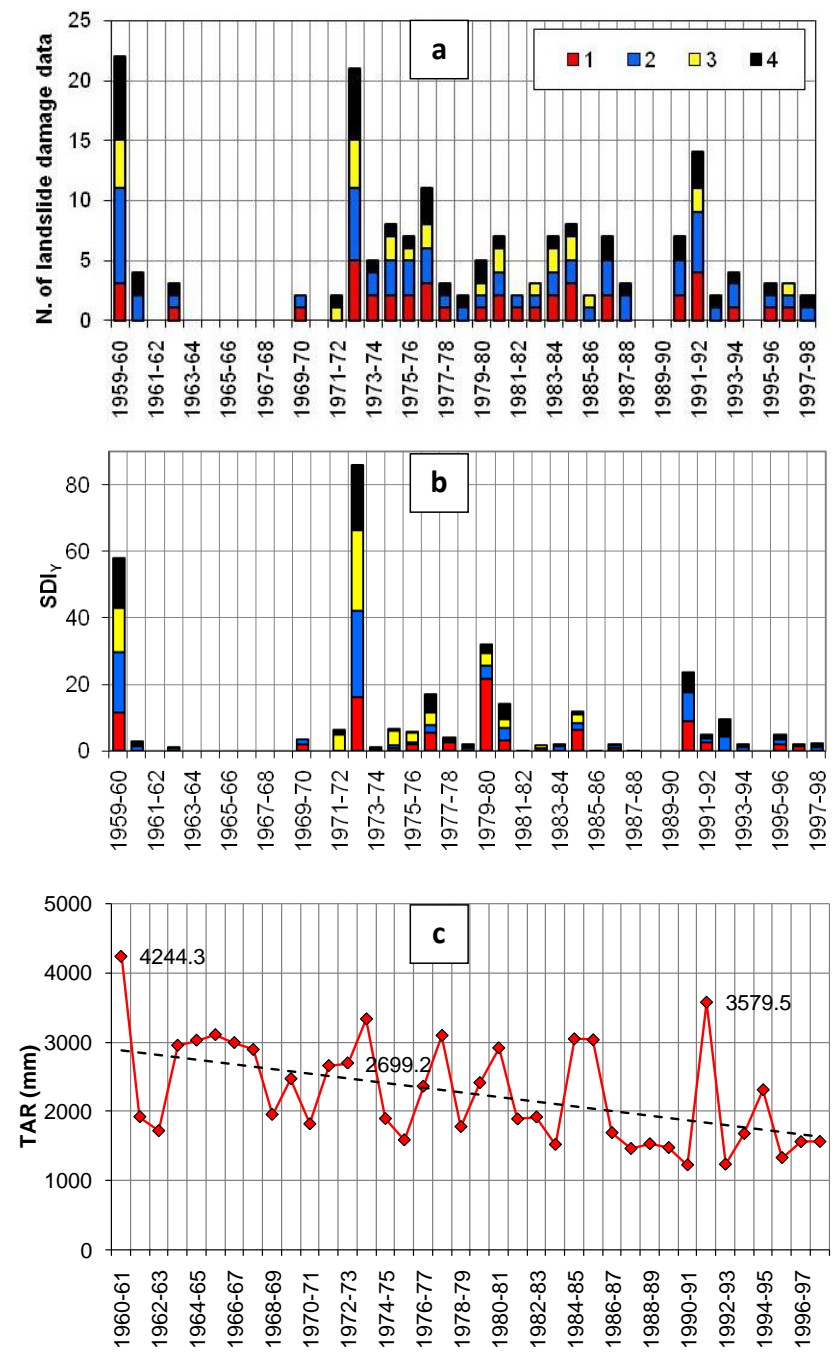

Fig. 3. (a) Number of landslide damage data recorded for each year of the study period. The four Polygons of the area, identified by the four numbers in the legend, are indicated with different colours. (b) $\mathrm{SDI}_{Y}$ : Simplified Damage Index assessed, Polygon by Polygon, for each year of the study period. (c) TAR: Total Annual Rainfall (the sum of the rainfall recorded at the four rain gauges of the study area) for each year of the study period (the dashed line represents the trend of this variable during the analysed period).

Yet, we can find either wet years $\left(K_{P}\right.$ equal to 1.11$)$ that were absolutely landslide-damage-free, or almost dry years $\left(K_{P}<0.5\right)$ during which some landslide damage data were recorded.

The behaviours of the other Polygons are almost the same: for each Polygon, high values of $\mathrm{SDI}_{Y}$ are generally recorded in years characterised by high values of $K_{P}$; nevertheless, high values of this parameter do not represent a sufficient condition for the occurrence of landslide damage.

This suggests that the occurrence of landslide damage is not simply and directly tied to the amount of rainfall. Consequently, in order to find results relevant for practical 
purposes, the distribution of rainfall during the periods in which damage is recorded must be investigated.

\section{Results}

The 169 landslide data gathered, chronologically sorted, cluster into 17 LPs and 11 LEs (Table 3). The entire area recorded landslide damage in $65 \%$ of the cases. In $25 \%$ of cases damage only affected Polygon N.3, and in $12 \%$ of cases damage concerned both Polygons N.3 and N.1. This can be tied to the morphology of these two Polygons, which are nearest to the coast and characterised by the lowest mean altitude and a more gentle morphology than the other two.

All of the LPs recorded in the study area simultaneously caused landslide damage in sectors located outside of the area, either to the north or the south (Petrucci et al., 1996; Petrucci and Polemio, 2009; SICI, 2009, available at: http: //www.irpi.cnr.it/). Figure 4 shows the main features of the LPs: each sector of the table, labelled with a letter from A to $\mathrm{F}$, contains the elements described in detail in the caption. Some of these features have been graphically represented to allow their visual comparison.

For each LP, the return periods of rainfall (RPs) are assessed for the rainfall accumulated over short $(1,2,3$ and 5 days), medium (7, 10 and 30 days) and long (60, 90 and 180 days) durations (Fig. 4 sector B). For each block of durations, the highest value of RP recorded within the block itself is considered as representative and is classified according to the classes defined in Sect. 2.1.

The Simplified Damage Index for Landslide Period $\left(\mathrm{SDI}_{\mathrm{LP}}\right)$ recorded in each Polygon, was ranked in the following classes: Class 1: SDI $<5$; Class 2: SDI=5-10; Class 3: SDI $>10$. The total values are represented graphically by the gray cells.

In addition, the seasonal distribution of landslide damage data has been graphically represented: the decades in which landslide damage occurred in a selected Polygon are shown in gray, and the landslide periods in which the data are included are in light gray. Only the months from September to May have been represented because the historical research carried out for the study period did not gather data for the other months.

When sorting the surveyed LPs in order of decreasing $\mathrm{SDI}_{\mathrm{LP}}$ (Fig. 4), four types of LPs can be identified.

\section{Type 1}

Two cases of this type were recognised in the study period (N.6 and N.1). Damage was severe: the $\mathrm{SDI}_{P}$ reaches Class 3, and the values of $\mathrm{SDI}_{\mathrm{LP}}$ are the highest of the series (85.89 for N.6 and 58.02 for N.1). The time span ranges between 160 and 170 days, starting in November. In these cases, all of the Polygons experienced landslide damage clustered in more than one episode. Rainfall can reach
Table 3. Landslide damage data collected for the study period sorted by hydrological year. At the top of the two blocks, the Polygon number, Polygon area and the percentage of study area occupied by the Polygon are indicated. For each HY, the landslide periods and landslide events are ordered chronologically and numbered sequentially. Landslide events are marked in gray. For each case, the date of the damage, the SDIP recorded in each Polygon, the percentage of the study area hit, and the SDI are shown.

\begin{tabular}{|c|c|c|c|c|c|c|c|c|}
\hline \multirow[b]{2}{*}{ HY } & \multicolumn{2}{|c|}{$\begin{array}{l}\text { Polygon number } \\
\text { Poligon area }\left(\mathrm{km}^{2}\right) \\
\% \text { of the area }\end{array}$} & $\begin{array}{l}1 \\
75.22 \\
19\end{array}$ & $\begin{array}{l}2 \\
110.99 \\
29\end{array}$ & $\begin{array}{l}3 \\
79.87 \\
21\end{array}$ & $\begin{array}{l}4 \\
123.2 \\
32\end{array}$ & \multirow{2}{*}{$\begin{array}{l}\% \text { of } \\
\text { the } \\
\text { area } \\
\text { hit }\end{array}$} & \multirow[b]{2}{*}{ SDI } \\
\hline & $\mathrm{N}$. & Date & \multicolumn{4}{|c|}{ SDIP } & & \\
\hline \multirow{8}{*}{ 1959-1960 } & & $22-26$ Nov 1959 & 10.05 & 11.18 & 4.84 & 5.42 & \multirow{8}{*}{100} & \multirow{8}{*}{58.02} \\
\hline & & 3 Dec 1959 & 0.15 & 0.01 & 0.13 & 0.33 & & \\
\hline & & 8 Jan 1960 & & 1.02 & & 0.03 & & \\
\hline & 1 & 15 Jan 1960 & 1.26 & 4.88 & & 6.56 & & \\
\hline & & $17 \mathrm{Feb} 1960$ & & 0.64 & & 0.77 & & \\
\hline & & 22 Mar 1960 & & 0.21 & 7.45 & 1.93 & & \\
\hline & & 7 Apr 1960 & & 0.07 & 0.86 & 0.10 & & \\
\hline & & 9 May 1960 & & 0.13 & & & & \\
\hline \multirow{3}{*}{ 1960-1961 } & \multirow{3}{*}{2} & 17 Sep 1960 & & 1.12 & & 1.35 & & \multirow{3}{*}{2.82} \\
\hline & & 26 Nov 1960 & & & & 0.07 & 60 & \\
\hline & & 17 Jan 1961 & & 0.28 & & & & \\
\hline
\end{tabular}

$1961-1962$

\begin{tabular}{|c|c|c|c|c|c|c|c|c|}
\hline $1962-1963$ & 3 & 31 Oct 1962 & 0.34 & 0.36 & & 0.04 & 79 & 0.75 \\
\hline $\begin{array}{l}1963-1964 \\
1964-1965 \\
1965-1966 \\
1966-1967 \\
1967-1968 \\
1968-1969\end{array}$ & & & & & & & & \\
\hline 1969-1970 & 4 & 17 Oct 1969 & 1.89 & 1.54 & & & 48 & 3.42 \\
\hline 1970-1971 & & & & & & & & \\
\hline $1971-1972$ & 5 & 18 Mar 1972 & & & 4.78 & 1.29 & 52 & 6.07 \\
\hline $1972-1973$ & 6 & $\begin{array}{l}\text { 1 Nov } 1972 \\
\text { 31 Dec } 1972 \\
\text { 2-4 Jan } 1973 \\
\text { 22 Mar 1973 } \\
\text { 26-30 Mar } 1973 \\
\text { 1-6 Apr } 1973\end{array}$ & $\begin{array}{l}0.51 \\
0.16 \\
5.05 \\
\\
2.01 \\
8.25\end{array}$ & $\begin{array}{l}0.22 \\
1.83 \\
1.26 \\
0.39 \\
3.65 \\
18.74\end{array}$ & $\begin{array}{l}2.81 \\
8.84 \\
9.73 \\
\\
\end{array}$ & $\begin{array}{l}1.92 \\
0.32 \\
1.12 \\
0.55 \\
4.55 \\
11.04\end{array}$ & 100 & 85.89 \\
\hline 1973-1974 & 7 & $\begin{array}{l}29 \text { Dec } 1973 \\
6 \text { Mar } 1974 \\
22 \text { Apr } 1974\end{array}$ & $\begin{array}{l}0.16 \\
0.13\end{array}$ & $\begin{array}{l}0.03 \\
0.10\end{array}$ & & 0.55 & 79 & 0.97 \\
\hline 1974-1975 & 8 & $\begin{array}{l}2 \text { Dec } 1974 \\
\text { 31 Dec } 1974 \\
\text { 16-18 Feb } 1975\end{array}$ & $\begin{array}{l}0.26 \\
0.36\end{array}$ & $\begin{array}{l}0.06 \\
0.55 \\
0.42\end{array}$ & $\begin{array}{l}4.24 \\
0.09\end{array}$ & 0.48 & 100 & 6.46 \\
\hline 1975-1976 & 9 & $\begin{array}{l}\text { 05 Nov } 1975 \\
\text { 14 Dec } 1975 \\
\text { 3 Jan } 1976\end{array}$ & $\begin{array}{l}0.16 \\
1.74\end{array}$ & $\begin{array}{l}0.03 \\
0.22 \\
0.32\end{array}$ & 2.77 & 0.32 & 10 & 5.55 \\
\hline 1976-1977 & 10 & $\begin{array}{l}5 \text { Nov } 1976 \\
24 \text { Nov } 1976 \\
13 \text { Dec } 1976 \\
11 \text { Feb } 1977\end{array}$ & $\begin{array}{l}0.78 \\
3.30 \\
1.26\end{array}$ & $\begin{array}{l}0.33 \\
0.56 \\
\\
\\
1.51\end{array}$ & $\begin{array}{l}0.78 \\
2.95\end{array}$ & $\begin{array}{l}0.72 \\
\\
3.27 \\
1.54\end{array}$ & 100 & 17.00 \\
\hline 1977-1978 & 11 & $\begin{array}{l}25 \text { Nov } 1977 \\
1 \text { Feb } 1978\end{array}$ & 2.53 & 0.50 & & 0.75 & 79 & 3.77 \\
\hline 1978-1979 & 12 & 26 Feb 1979 & & 0.80 & & 0.96 & 60 & 1.76 \\
\hline 1979-1980 & 13 & $\begin{array}{l}\text { 06 Nov } 1979 \\
\text { 14 Jan } 1980\end{array}$ & 21.62 & 4.00 & 3.83 & $\begin{array}{l}1.92 \\
0.62\end{array}$ & 100 & 31.99 \\
\hline 1980-1981 & 14 & $\begin{array}{l}\text { 10 Jan } 1981 \\
\text { 01 Mar } 1981\end{array}$ & $\begin{array}{l}1.97 \\
0.99\end{array}$ & $\begin{array}{l}3.82 \\
0.07\end{array}$ & $\begin{array}{l}1.76 \\
0.88\end{array}$ & 4.43 & 100 & 13.91 \\
\hline 1981-1982 & 15 & 28 Nov 1981 & 0.16 & 0.03 & & & 48 & 0.19 \\
\hline $1982-1983$ & 16 & $11 \mathrm{Sep} 1982$ & 0.79 & 0.06 & 0.70 & & 68 & 1.55 \\
\hline
\end{tabular}


Table 3. Continued.

\begin{tabular}{|c|c|c|c|c|c|c|c|c|}
\hline \multirow[b]{2}{*}{ HY } & \multicolumn{2}{|c|}{$\begin{array}{l}\text { Polygon number } \\
\text { Poligon area }\left(\mathrm{km}^{2}\right) \\
\% \text { of the area }\end{array}$} & $\begin{array}{l}1 \\
75.22 \\
19\end{array}$ & $\begin{array}{l}2 \\
110.99 \\
29\end{array}$ & $\begin{array}{l}3 \\
79.87 \\
21\end{array}$ & $\begin{array}{l}4 \\
123.2 \\
32\end{array}$ & \multirow{2}{*}{$\begin{array}{l}\% \text { of } \\
\text { the } \\
\text { area } \\
\text { hit }\end{array}$} & \multirow[b]{2}{*}{ SDI } \\
\hline & & Date & \multicolumn{4}{|c|}{$\mathrm{SDI}_{\mathrm{P}}$} & & \\
\hline 1983-1984 & 17 & $\begin{array}{l}5 \text { Dec } 1983 \\
19 \text { Apr } 1984\end{array}$ & $\begin{array}{l}0.05 \\
0.39\end{array}$ & $\begin{array}{l}0.85 \\
0.03\end{array}$ & $\begin{array}{l}0.04 \\
0.35\end{array}$ & 0.02 & 100 & 1.75 \\
\hline 1984-1985 & 18 & $\begin{array}{l}5 \text { Dec } 1984 \\
\text { 9 Jan } 1985 \\
\text { 21 Jan } 1985\end{array}$ & $\begin{array}{l}0.30 \\
1.29 \\
4.75\end{array}$ & $\begin{array}{l}0.02 \\
1.95\end{array}$ & $\begin{array}{l}0.26 \\
2.27\end{array}$ & 0.84 & 100 & 11.68 \\
\hline 1985-1986 & 19 & 21 Mar 1986 & & 0.08 & & & 29 & 0.08 \\
\hline 1986-1987 & 20 & $\begin{array}{l}\text { 12 Dec } 1986 \\
\text { 19 Jan } 1987 \\
\text { 26 Feb } 1987\end{array}$ & $\begin{array}{l}0.16 \\
0.69\end{array}$ & $\begin{array}{l}0.20 \\
0.09 \\
0.56\end{array}$ & 0.13 & $\begin{array}{l}0.11 \\
0.07\end{array}$ & 100 & 2.00 \\
\hline $1987-1988$ & 21 & $\begin{array}{l}29 \text { Sep } 1987 \\
15 \text { Oct } 1987\end{array}$ & & $\begin{array}{l}0.08 \\
0.01\end{array}$ & & 0.10 & 60 & 0.19 \\
\hline $\begin{array}{l}1988-1989 \\
1989-1990\end{array}$ & & & & & & & & \\
\hline 1990-1991 & 22 & $\begin{array}{l}26 \text { Oct } 1990 \\
29 \text { Nov } 1990 \\
29 \text { Dec } 1990\end{array}$ & $\begin{array}{l}0.95 \\
7.87\end{array}$ & $\begin{array}{l}0.17 \\
4.16 \\
4.42\end{array}$ & & $\begin{array}{l}5.00 \\
1.06\end{array}$ & 79 & 23.64 \\
\hline 1991-1992 & 23 & $\begin{array}{l}\text { 13 Nov } 1991 \\
\text { 4 Feb } 1992 \\
\text { 16 Feb } 1992 \\
\text { 26 Feb } 1992 \\
\text { 16-20 Mar } 1992\end{array}$ & $\begin{array}{l}1.10 \\
0.05 \\
1.26 \\
\\
0.05\end{array}$ & $\begin{array}{l}0.20 \\
0.0035 \\
0.87 \\
0.08 \\
0.01\end{array}$ & 0.13 & $\begin{array}{l}0.77 \\
0.10 \\
0.01\end{array}$ & 100 & 4.69 \\
\hline 1992-1993 & 24 & 5 Jan 1993 & & 4.24 & & 5.10 & 60 & 9.34 \\
\hline 1993-1994 & 25 & $\begin{array}{l}25 \text { Nov } 1993 \\
4 \text { Mar } 1994\end{array}$ & 0.16 & $\begin{array}{l}0.03 \\
0.80\end{array}$ & & 0.96 & 79 & 1.95 \\
\hline 1994-1995 & & & & & & & & \\
\hline 1995-1996 & 26 & 21 Feb 1996 & 1.89 & 1.47 & 0.04 & 1.35 & 100 & 4.76 \\
\hline 1996-1997 & 27 & 8 Oct 1996 & 1.26 & 0.23 & & & 48 & 1.50 \\
\hline $1997-1998$ & 28 & 8 Dec 1997 & & 0.96 & & 1.15 & 60 & 2.12 \\
\hline
\end{tabular}

the maximum class of RP for almost all of the durations (as in N.1) or can show the highest RPs for medium and long durations (as in case N.6). The highest RP is 57 years, the lowest is 2 years, and the average is 18 years. For each rain gauge, the highest values of RP fall primarily in the medium duration and secondly in the long duration rainfalls.

\section{Type 2}

In the study period, three cases of LP of Type 2 occurred (N.13, N.22 and N.10). The SDI LP shows high values (from 31.99 , in the case N.13, to 17, in the case N.10), but in general, in each Polygon, the $\mathrm{SDI}_{P}$ reaches at most Class 2 and in only one case Class 3 (Polygon 1 in LP N.13). In these LPs, between the last decade of October and the second one of February, for periods ranging between 70 and 110 days, two or more episodes of landslide damage affected the whole (or almost the whole) study area. Return periods can reach the maximum class for approximately all of the durations (as in N.10) or can show higher values for short and medium durations (as for N.22 and 13). For this type of LP, the numerical values of RPs are the highest among all the types, ranging from 200 to 3 years, with 52 years as the average.

\section{Type 3}

Six cases of this type were recognised in the analysed period (N.14, N.18, N.9, N.25, N.17, and N.7). The SDI LP ranges between 13.91 (N.14) to 0.97 (N.7), and, for each Polygon, $\mathrm{SDI}_{P}$ is classified as Class 1, except in the case of N.18. The LP N.7, characterised by the lowest value of SDI $\mathrm{LP}_{\mathrm{LP}}$, seems to be different from the rest of the group: it seems particularly centred on Polygon N.2, where an outlier value of daily rainfall (return period of about 200 years) was recorded. Meanwhile, in the adjacent Polygons, the RP was less than 3 years. In four of the six recorded cases, all of the Polygons recorded landslide damage, and, in the remaining cases, Polygon 3 was not hit.

On average, the duration was 95 days, during which two or more episodes were recorded: they can start between November and January and last until the end of April. The value of $\mathrm{SDI}_{\mathrm{LP}}$ seems to be inversely proportional to the duration of the LP: the cases characterised by minor durations (i.e., N.18, lasting 50 days, and N.14, 70 days) show the highest values of SDI LP.

Rainfall shows almost usual values: return periods are often under the threshold of five years or reach at most Class 1 or 2, except for three cases (N.18, N.9 and N.7) that show some values in Class 3. Numerically, except for the outlier N.7, return periods range from 2 to 17 years, with an average of 6 years; the highest values primarily concern long and secondly short durations.

\section{Type 4}

The six LPs composing this group (N.8, N.23, N.11, N.2, N.20 and N.21) show two main characteristics: a) for each block of rainfall, the RP is always below the threshold of five years, and b) both $\mathrm{SDI}_{\mathrm{LP}}$ and $\mathrm{SDI}_{P}$ show quite low values. The duration ranges between 30 and 180 days, with an average of 88 days. The LPs can occur in a wide period, ranging from the beginning of the HY (second decade of September) and lasting until the beginning of spring.

In Fig. 5, the RP, $S_{L D} D_{L P}$ and the period of occurrence of each type of landslide period are schematised. Both the exceptionality (maximum value) and the typical values (average) are graphically represented: these values are used as upper and lower bounds of the bars expressing RP and $\mathrm{SLD}_{L P}$, respectively. Similarly, the period in which the type of event occurred is represented using a bar.

Landslide damage seems not to be confined to a restricted period but extends instead from autumn to spring: the cases starting earlier concern Type 4 (starting in the second decade of September), while those extending longer concern Type 1 (also lasting until the 1st decade of May). No strong differences can be appreciated in the seasonal distributions of Types 1, 2 and 3: the most important difference can be observed between Types 1 and 4 (which are the most and least severe types, respectively). 


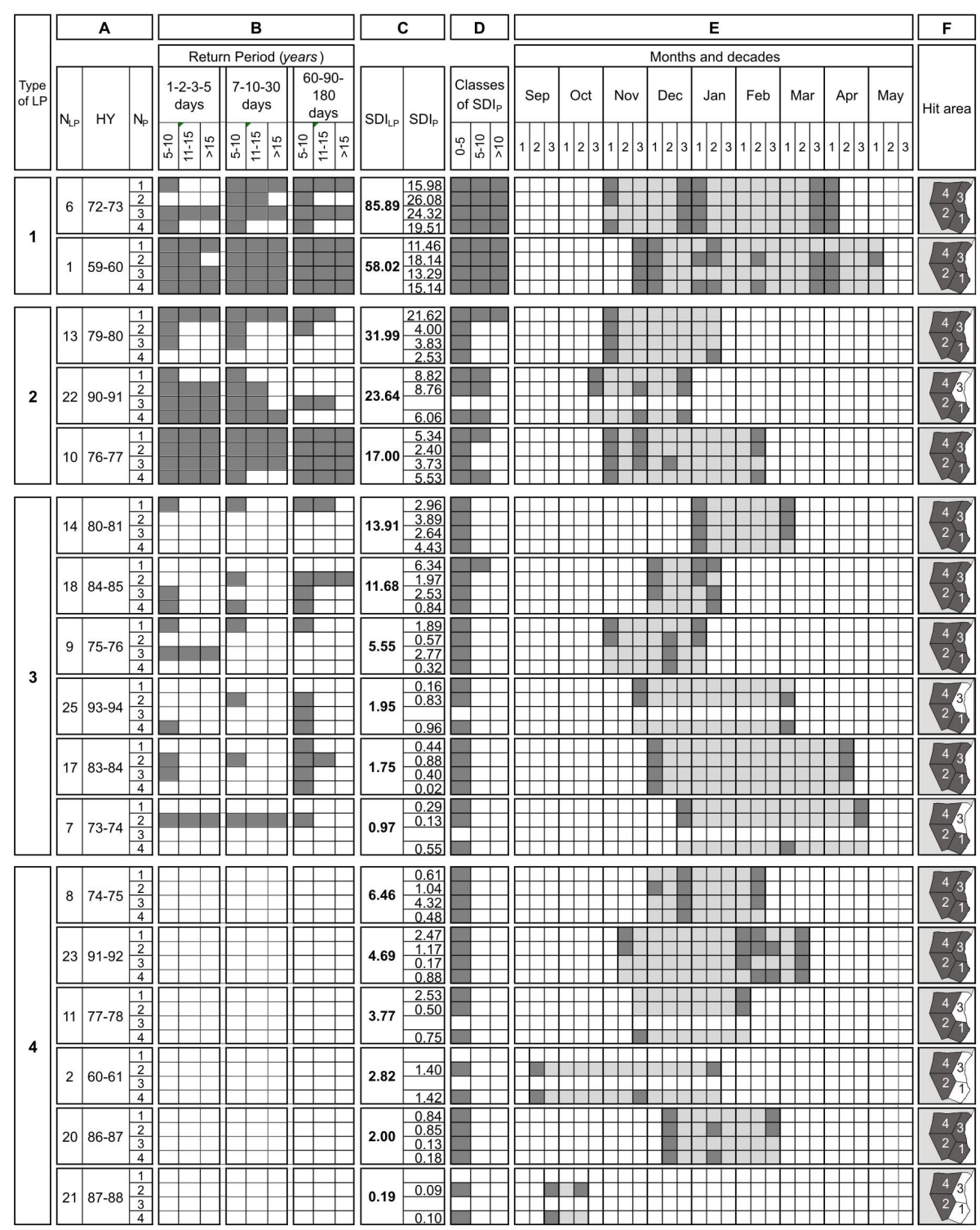

Fig. 4. Main features of surveyed LPs. A: $\mathrm{N}_{\mathrm{LP}}$ : number that identifies the landslide period; HY: hydrological year in which the landslide period occurred; $\mathrm{N}_{\mathrm{P}}$ : identification number of the Polygon. B: classification of the return period of rainfall (years) for short (1, 2, 3, 5 days), medium (7, 10 and 30 days) and long lasting rainfall (60, 90 and 180 days), graphically represented by gray cells. C: SDI LP: Simplified Damage Index of the Landslide Period, which expresses the total damage caused over the whole area by the analysed LP; SDI $:$ Simplified


Landslide Period ranked into classes, represented graphically by gray cells. E: grid of seasonal distribution of landslide damage data. The months of the HY, divided into decades (indicated by the numbers 1,2 and 3), are represented by the columns, and the rows indicate the Polygons of the study area. In gray are shown the decades in which landslide damage occurred in a selected Polygon, while light gray shows the landslide period in which the data are included. F: study area: Polygons in which landslide damage data are recorded during each LP have been coloured.

LPs developing between September and February (Type 4) and characterised by RPs under the threshold of five years do not seem to accumulate a sufficient amount of rainfall to cause relevant landslide damage. On the other hand, Type 1LPs, starting in November and lasting until May, show RPs ranging from 15 to 60 years and can cause severe landslide damage over the whole study area.
The highest values of RP, characterising Type 2, do not cause very high damage, while RPs lower than 50 years cause the most severe damage. This indicates that the study area is most prone to undergoing landslide damage after prolonged rainfall periods, lasting up to 180 days and characterised by moderately high RPs, instead of after short and very intense rainfall occurring during rainy periods shorter than 110 days. 
Types 3 and 4, characterised by lower RPs (under 17 years), occur over a wide period (from September to April) and induce medium/low damage $\left(\mathrm{SDI}_{\mathrm{LP}}<14\right)$.

Besides the LPs, in the study period 11 Landslide Events also occurred (Fig. 6). The sections of this figure contain, for LEs, the same elements used in Fig. 4 to describe the LPs. The only differences concern damage, which in this case is expressed as $\mathrm{SDI}_{\mathrm{LE}}$ (Simplified Damage Index of Landslide Event), and rainfall. In these cases, in fact, the RPs are always lower than five years. In order to describe the amount of rainfall, we used average cumulative rainfall for each duration as a reference value (from 1 to 180 days). Therefore, to express the exceptionality of the rain that triggered an LE, for a selected duration $i$, we assess a factor $F_{i}$, defined as in Eq. (2):

$F_{i}=\left(\mathrm{CR}_{i}-\mathrm{ACR}_{i}\right) / \mathrm{CRA}_{i} \times 100$

where $\mathrm{CR}_{i}$ is the Cumulative Rainfall for the duration $i$ ( $i=1$, $2,3,5,7,10,30,60,90$ and 180 days) and $\mathrm{ACR}_{i}$ is the Average of Cumulative Rainfall for the duration $i$, assessed basing on the available 39 -year series. In practice, $F_{i}$ represents the percentage of cumulative rainfall for a selected duration which exceeds the average value for the same duration, based on the available data. The obtained values of $\mathrm{F}_{i}$ are classified as follows: Class 1: $F=0-5$; Class 2: $F=5-20$; Class 3: $F>20$.

We graphically present these data in Fig. 6 by means of the highest value of $F_{i}$ recorded in each block of durations (gray cells).

The 11 surveyed LEs have been ranked in order of decreasing $\mathrm{SDI}_{\mathrm{LE}}$ : this parameter is always under 10, and in only one case, for Polygon 4, does the $\mathrm{SDI}_{P}$ show a Class 2. In all of the other LEs, the class for each Polygon is one.

We deal with isolated events that occur between September and April and, except for case N.26, do not simultaneously hit the entire area but rather only some Polygons. Most of these represent a local "secondary" effect of landslide periods mainly affecting sectors located outside of the study area and extending along the eastern coast, both north and south of the area. In two cases, landslide damage is recorded only in the study area (N.15 and N.16), and in only one case (N.27), landslide damage occurred during events that simultaneously hit the Tyrrhenian side of Calabria.

The amount of rain inducing LEs does not show very high values. This suggests that rainfall might have served as the final triggering cause of the landslide event, but that additional processes may have previously destabilised the slopes, such as anthropogenic activities. For cases characterised by the activation of shallow landslides in soils, we can also hypothesise the important role played by high hourly-intensity storms. This role cannot be appreciated because the rain gauges of the area only record daily rainfall.

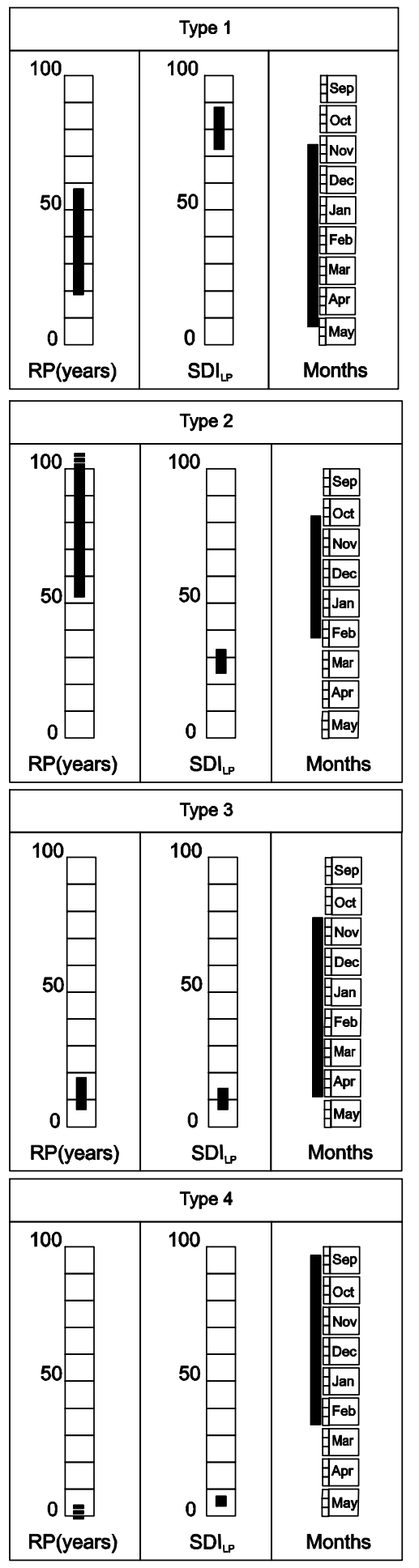

Fig. 5. Types of LPs affecting the study area. For each type, three columns are used: the first indicates the RPs (the limits of the bar are the average and maximum value surveyed, respectively), the second represents the $\mathrm{SDI}_{\mathrm{LP}}$ (the limits of the bar are the average and maximum value surveyed, respectively), and the third indicates the month during which the analysed type of event occurred. 


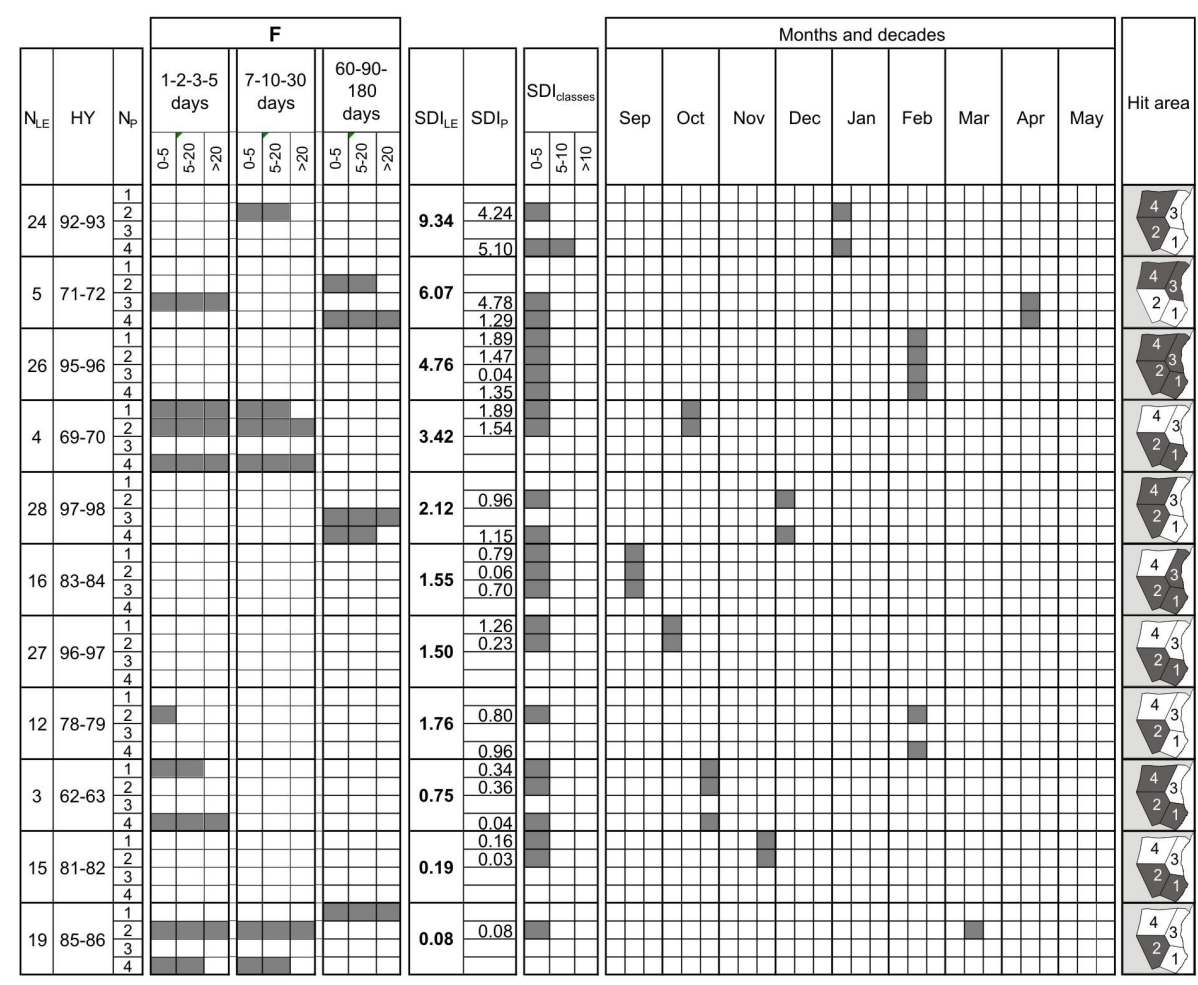

Fig. 6. Main features of identified LEs surveyed in the study period. All of the columns have the same meaning as in Fig. 4: the only differences concern damage, which in this case is expressed as $\mathrm{SDI}_{\mathrm{LE}}$ (Simplified Damage Index of Landslide Event) and rainfall. In these cases, to describe the amount of rainfall, we use the factor $F$, which expresses the percentage of cumulative rainfall of a certain duration that exceeds the average of cumulative rainfall of the analysed duration, assessed based on the available rainfall series.

\section{Uncertainty and limitations of the methodology}

The limitations of the proposed approach depend on both data requisites and assumptions. Limitations concerning data depend on the following factors:

1. The approach requires a reliable rainfall database. If some daily rainfall data are missing during a landslide period, the assessment of rain preceding landslide triggering could be underestimated. Furthermore, to obtain statistically significant results, the length of each rainfall series should exceed 30 years.

2. The approach requires a reliable historical database of landslide damage. For the reasons discussed in Sect. 2.2, there is no way to be sure that the historical series is complete. This introduces an uncertainty that can be reduced by means of cross-checking different archives and information sources, but cannot be eliminated entirely.

3. The analysed period must be long enough: a lower threshold is 10 years, but a longer observation period can ensure that all the main types of LP are analysed.
Limitations depending on simplifications, introduced to allow the elaboration and comparative analysis of rainfall and landslide damage data, can be summarised as follows:

1. Considering that historical documents do not present maps of areas hit by landslides, a precise localisation of damaged (and damageable) sites requires further research or a georeferencing process of historical data using landslide maps, if available, of the study area.

2. It should be taking into account that a recent urban development of the study area can lead to either increase or decrease of landslide susceptibility. Stabilising modifications, as reinforcement of slopes, can determine a reduction of landslide susceptibility; de-stabilising modifications, as cut for roads construction or urbanisation carried out inside landslide areas, can increase landslide susceptibility. Moreover, the augmented number of vulnerable elements can increase the effects of reactivations of landslides that in the past were activated in a less populated framework.

3. Damage data assessment is carried out by means of a simplified procedure based on a series of assumptions concerning the value of vulnerable elements, which are 
arbitrarily assigned based on the damage reports contained in the Calabrian landslides database.

4. Finally, it must be taken into account that the methodology can be applied to each area for which rainfall and landslide damage data are available. Nevertheless, the results obtained for a specific study area only work for that area and cannot be applied in other regions.

\section{Conclusions}

We present a methodological approach based on the comparative analysis of historical series of landslide damage and daily rainfall data, aiming to characterise the main types of Landslide Periods. These are defined as periods shorter than a hydrological year during which one or more landslide damage events occurred in one or more sectors of a study area.

Cumulative rainfalls preceding landslide activation, expressed by means of their return periods, are compared to landslide damage, expressed by a Simplified Damage Index. This comparison allows us to identify the different types of LPs that affected a study area in the past and that could hit it again in the future. The proposed methodology is a largescale approach that analyses a wide number of landslides aiming to obtain general results that can be used for wide areas affected by landslide damage.

A case study performed for a 39-year series of data concerning a study area located in NE Calabria (Italy) allows us to identify four main types of LPs that affected the study area in the past. Although the trend of landslide damage seems to be substantially decreasing from 1959 to 1998 (the period for which rainfall data are available), we hypothesise that, if new landslide periods occur in the area, they will show the same features as for past cases. This can be hypothesised because the study area did not undergo strong anthropogenic modifications in recent years, so the number and location of vulnerable elements is unchanged. On the contrary, in areas characterised by strong recent anthropogenic development, it must be taken into account that urbanisation can increase the landslide susceptibility because of terrain modifications tied to the construction of roads and buildings. In addition, even if no pejorative modifications are carried out, the urban expansion can often be performed in landslide prone areas. This increases the number of vulnerable elements and, during LPs, can amplify landslide damage.

The results show a tendency for the analysed area to be damaged only during periods characterised by sequences of rainy days (landslide periods), instead of isolated cases (landslide events), during which only a small amount of damage is recorded. The severest type of LP (Type 1) shows a low frequency (two cases in 39 years). Type 1 is made up of several episodes that caused high damage throughout the area, during rainy periods of 160-170 days developing from November to May. The average RP is 18 years, while the highest recorded value is 57 years: the highest RPs fall primarily in the medium duration (7-30 days) and secondarily in the long duration (60-180 days) rainfalls.

A slightly lower severity level and slightly higher frequency (three cases in 39 years) characterise Type 2 . These are relatively short LPs (70 to 110 days) that occur between October and February, causing damage throughout almost all of the area. The RPs are the highest among all of the types of LPs, with an average of 52 years and a maximum of 200 years, but their short duration prevents damage from reaching the value of Type 1 .

The study area seems to be most prone to damage caused by prolonged rainfall, even though these are characterised by return periods lower than 50 years instead of rainfall events characterised by shorter durations and RPs higher than 100 years.

Types 3 and 4 show the same frequency (six cases in 39 years); they both caused damage lower than that caused by Types 1 and 2. Type 3 shows a mean RP of 6 years, and Type 4 is characterised by all RPs being under 5 years.

Low damage levels and ordinary rainfall characterise LEs.

The obtained results can be used, coupled with mediumterm meteorological forecasting, to anticipate the approach of a landslide period and to be ready to manage emergency phases.

In this work, we only show a regional approach to this problem. Nevertheless, by comparing the obtained results with historical data gathered for each municipality and with landslide inventory maps, a detailed identification of the most damaged (and damageable) sites can be carried out (although with the uncertainty intrinsic to historical data). Defensive measures and attention during emergency plan redaction must be directed first at these areas.

More generally, the results of this activity can be used for practical purposes to define scenarios and strategies for risk management, to suggest priorities in policy towards disaster mitigation and preparedness and to predispose defensive measures and civil protection plans ranked according to the types of LPs.

Edited by: F. Castelli

Reviewed by: two anonymous referees

\section{References}

Au, S. W. C.: Rain induced slope instability in Hong Kong, Eng. Geol., 51, 1-36, 1998.

Barnikel, F. and Becht, M.: A historical analysis of hazardous events in the Alps - the case of Hindelang (Bavaria, Germany), Nat. Hazards Earth Syst. Sci., 3, 625-635, 2003, http://www.nat-hazards-earth-syst-sci.net/3/625/2003/.

Blong, R.: Natural hazards risk assessment: an Australian perspective, Benfield Hazard Research Centre, Dept. Earth Science, University College, London, 2004.

Caine, N.: The rainfall intensity-duration control of shallow landslides and debris flows, Geogr. Ann. A, 62(1-2), 23-27, 1980. 
Campbell, R.: Soil slips, debris flows and rainstorms in the Santa Monica Mountains and vicinity, Souther California, USGS Professional Paper, 851, 51 pp., 1975.

Cancelli, A. and Nova, R.: Landslides in soil debris cover triggered by rainstorm in Valtellina (Central Alps - Italy), IV Int. Conf. and field Workshop on Landslides. Tokyo, 1, 267-272, 1985.

Cannon, S. H. and Ellen, S. D.: Rainfall conditions for abundant debris avalanches, S. Francisco Bay region, California, California Geology, 38(12), 267-272, 1985.

Carrara, A., Merenda, L., Nicoletti, P. G., and Sorriso-Valvo, M.: Slope instability in Calabria, Italy, Polish-Italian Seminar on Superficial Mass Movement in Mountain Regions, Szymbark, Instit. Meteor. i Gospod. Wodnej, Warszawa, 47-62, 1979.

Cascini, L. and Versace, P.: Eventi pluviometrici e movimenti franosi, National Meeting of Geotechnics, Bologna (Italy), 3, 171184, 1986.

CASMEZ: Carta geologica della Calabria in scala 1:25000. Fogli Albidona, Alessandria, Amendolara, Canna, Castroregio, Montegiordano, Montegiordano Scalo, Nocara, Oriolo, Rocca Imperiale, Roseto Capo Spulico, 1970-1971.

Chien-Yuan, C., Tien-Chien, C., Fan-Chieh, Y., Wen-Hui, Y., and Chun-Chieh, T.: Rainfall duration and debris-flow initiated studies for real-time monitoring, Environ. Geol., 47, 715-724, 2005.

Colten, C. E. and Sumpter, A. R.: Social memory and resilience in New Orleans, Nat. Hazards, 48(3), 355-364, 2008.

Corominas, J.: Landslides and climate, 8th International Symposium on Landslides, Cardiff (Galles), 4, 1-33, 2001.

Crozier, M. (Ed.): Climatic triggering of landslide episodes, in: Landslides: causes, consequences and environment, Croom Helm, 169-192, 1986.

Cuesta, M. J. D., Sanchez, M. J., and Garcia, A. R.: Press archives as temporal records of landslides in the North of Spain: relationships between rainfall and instability slope events, Geomorphology, 30, 125-132, 1999.

Dai, F. C. and Lee, C. F.: Frequency-volume relation and prediction of rainfall-induced landslides, Eng. Geol., 59(3-4), 253266, 2001.

Dore, M. H. I.: Forecasting the conditional probabilities of natural disasters in Canada as a guide for disaster preparedness, Nat. Hazards, 28, 249-269, 2003.

Finlay, P. G., Fell, R., and Maguire, P. K.: The relationship between the probability of landslide occurrence and rainfall, Can. Geotech. J., 34, 811-824, 1997.

Flageollet, J. C., Maquaire, O., Martin, B., and Weber, D.: Landslides and climatic conditions in the Barcelonette and Vars basins (southern French Alps, France), Geomorphology, 30, 65-78, 1999.

Floris, M. and Bozzano, F.: Evaluation of landslide reactivation: a modified rainfall threshold model based on historical records of rainfall and landslides, Geomorphology, 94, 40-57, 2008.

Glade, T.: Landslide hazard assessment and historical landslide data - An inseparable couple?, in: The use of historical data in natural hazard assessments, Advances of Technological and Natural Hazard Research, edited by: Glade, T., Albini, P., and Frances, F., Kluwer, 153-169, 2001.

Glaser, R. and Stangl, H.: Climate and floods in central Europe since AD 1000: data, methods, results and consequences, Surv. Geophys., 25, 485-510, 2004.
Govi, M., Mortara, G., and Sorzana, P. F.: Eventi ideologici e frane, Geol. Appl. e Idrogeol, XX(2), 359-375, 1985.

Guzzetti, F., Cardinali, M., and Reichenbach, P.: The AVI project: a bibliographical and archive inventory of landslides and floods in Italy, Environ. Manag., 18, 623-633, 1994.

Guzzetti, F.: Landslide fatalities and the evaluation of landslide risk in Italy, Eng. Geol., 58, 89-107, 2000.

Guzzetti, F., Peruccacci, S., Rossi, M., and Stark, C. P.: Rainfall thresholds for the initiation of landslides in central and southern Europe, Meteorol. Atmos. Phys., 98, 239-267, 2007.

Ibsen, M. L. and Brunsden, D.: The nature, use and problems of historical archives for the temporal occurrence of landslides, with specific reference to the South coast of Britain, Ventnor, Isle of Wight, Geomorphology, 15, 241-258, 1996.

Jibson, R. W.: Debris flows in southern Puerto Rico, Geological Society of America, 236, 29-55, 1989.

Keefer, D. K., Wilson, R. C., Mark, R., Brabb, E. E., Brown III., W. M., Ellen, S. D., Harp, E. L., Wieczorek, G. F., Alger, C. S., and Zatkin, R. S.: Real time landslide warning during heavy rainfall, Science, 238, 921-925, 1987.

Kirschbaum, D. B., Adler, R., Hong, Y., Hill, S., and Lerner-Lam, A. L.: A global landslide catalog for hazard applications: method, results and limitations, Nat. Hazards, doi:10.1007/s11069-009-9401-4, available at: http://www. springerlink.com/content/572u405t63061651/, 2009.

Lanzafame, G. and Mercuri, T.: Interruzioni ferroviarie in Calabria conseguenti a fenomeni naturali (1950-1973), Geodata No. 3, CNR-IRPI, Rende (Italy), 1975.

Llasat, M. C., Barriendos, M., and Barrera, A.: The use of historical data in flood risk assessment, Application to Catalonia (NE Spain) 14th-20th centuries, in: View from the South, Environmental stories from the Mediterranean Word, edited by: Armiero, M., CNR, Istituto di Studi sulle Società del Mediterraneo, Napoli (Italy), 95-11, 2006.

Middelmann, M. H.: Impact of natural disasters, in: Natural Hazards in Australia identifying Risk Analysis requirements, Risk and Impact Analysis Group, Geospatial and Earth Monitoring Division, http://www.ga.gov.au/hazards/reports/nhiar, last accessed: 20 February 2009.

Ogniben, L.: Schema geologico della Calabria in base ai dati odierni, Geologica Romana, 12, 243-585, 1973.

Petley, D. N., Dunning, S. A., and Rosser, N. J.: The analysis of global landslide risk through the creation of a database of worldwide landslide fatalities, in: Landslide Risk Management, edited by: Hungr, O., Fell, R., Counture, R., and Ebergardt, E., Balkema, Amsterdam, 367-374, 2005.

Petrucci, O. and Gullà, G.: A Support Analysis Framework for mass movement damage assessment: applications to case studies in Calabria (Italy), Nat. Hazards Earth Syst. Sci., 9, 315-326, 2009a, http://www.nat-hazards-earth-syst-sci.net/9/315/2009/.

Petrucci, O. and Gullà, G.: A simplified method for landslide damage scenario assessment based on historical data, Nat. Hazards, available at: http://www.springerlink.com/content/ b1114gn2k206611v/, doi:10.1007/s11069-009-9398-8, $2009 \mathrm{~b}$.

Petrucci, O. and Pasqua, A. A.: The study of past damaging hydrogeological events for damage susceptibility zonation, Nat. Hazards Earth Syst. Sci., 8, 881-892, 2008, http://www.nat-hazards-earth-syst-sci.net/8/881/2008/. 
Petrucci, O. and Polemio, M.: The role of meteorological and climatic conditions in the occurrence of damaging hydro-geologic events in Southern Italy, Nat. Hazards Earth Syst. Sci., 9, 105118,2009 ,

http://www.nat-hazards-earth-syst-sci.net/9/105/2009/.

Petrucci, O., Polemio, M., and Pasqua, A.: Analysis of damaging hydro-geological events: the case of Calabria region (southern Italy), Environmen. Manage., 43(3), 483-495, 2008.

Petrucci, O., Versace, P., and Pasqua, A. A.: Frane e alluvioni in provincia di Cosenza fra il 1951 ed il 1960: ricerche storiche nella documentazione del Genio Civile. III Quaderno dell'Osservatorio di Documentazione del Dipartimento di Difesa del Suolo (UNICAL), Rubbettino, Soveria Mannelli (Italy), 316 pp., 2009.
Polemio, M. and Petrucci, O.: Occurrence of landslide events and the role of climate in the twentieth century in Calabria, Southern Italy, Quarterly Journal of Engineering Geology and Hydrogeology, in press, 2009.

Sabato, L. and Tropeano, M.: Fiumara: a kind of high hazard river, Phys. Chem. Earth, 29(10), 707-715, 2004.

Schmidt, J. and Dikau, R.: Modelling historical climate variability and slope stability, Geomorphology, 60, 433-447, 2004.

Swiss Re: Floods - an insurable risk?, Zurich, 48 pp., 1998.

Tortorici, L.: Lineamenti geologico-strutturali dell'Arco CalabroPeloritano, Rendiconti della Società Italiana di Mineralogia e Petrologia, 38, 972-940, 1982.

Versace, P., Ferrari, E., Fiorentino, M., Gabriele, S., and Rossi, F.: Valutazione delle piene in Calabria, CNR-IRPI, Geodata No. 30, Rende (Italy), 1989. 